\title{
The oeconomy of nature: an interview with Margaret Schabas
}

MARGARET LYNN SCHABAS (Toronto, 1954) is professor of philosophy at the University of British Columbia in Vancouver and served as the head of the Philosophy Department from 2004-2009. She has held professoriate positions at the University of Wisconsin-Madison and at York University, and has also taught as a visiting professor at Michigan State University, University of Colorado-Boulder, Harvard, CalTech, the Sorbonne, and the École Normale de Cachan. As the recipient of several fellowships, she has enjoyed visiting terms at Stanford, Duke, MIT, Cambridge, the LSE, and the MPI-Berlin. In addition to her doctorate in the history and philosophy of science and technology (Toronto 1983), she holds a bachelor of science in music (oboe) and the philosophy of science (Indiana 1976), a master's degree in the history and philosophy of science (Indiana 1977), and a master's degree in economics (Michigan 1985).

She has published four books and over forty articles or book chapters in science studies. Some of the journals in which her articles can be found are Isis, Monist, History of Political Economy, Public Affairs Quarterly, Daedaelus, Journal of Economic Perspectives, and Studies in the History and Philosophy of Science. Her first book, A world ruled by number (1990) examines the emergence of mathematical economics in the second half of the nineteenth century. Her second book, The natural origins of economics (2005), traces the transformation of economics from a natural to a social science. She also has two co-edited collections, Oeconomies in the age of Newton (2003), with Neil De Marchi, and David Hume's political economy (2008), with Carl Wennerlind. She is currently writing a monograph on Hume's economics, as well as articles on the history and philosophy of bioeconomics. She is currently president of the History of Economics Society.

EJPE interviewed Margaret Schabas at the University of British Columbia in March 2013. In this interview, she recounts her earliest foray into the history and philosophy of economics, the conceptual trade between economics and natural science, and her most recent undertaking: the history and philosophy of bioeconomics.

EJPE's NotE: This interview was conducted by C. Tyler DesRoches, PhD candidate at the University of British Columbia in Vancouver and a co-editor of the Erasmus Journal for Philosophy and Economics. 
EJPE: Professor Schabas, can you begin by describing how it is that you first became interested in the history and philosophy of economics. After all, you hold a bachelor of science in music?

MARGARET SCHABAS: Well, you cannot take up music later in life, but I was always studying philosophy and physics along with music, and left open the option of an academic career. As a master's student in the history and philosophy of science (HPS) at Indiana University, I was encouraged to take a course from $\mathrm{H}$. Scott Gordon and that got me interested in economics. Scott also taught Wade Hands and Harold Kincaid. He was about the only scholar teaching the history and philosophy of economics in a HPS department. When I decided to leave Indiana, spending a gap year in London to study music, he suggested I do my doctorate back in my home city of Toronto, which also had a HPS program. My supervisors were Sam Hollander and Trevor Levere.

At that time, the philosophy of economics as a subfield of the philosophy of science was really just emerging. Did you also realize that you were a part of this movement that included people like Dan Hausman and Alex Rosenberg?

No I did not, but I met them both within the first few years after my PhD of 1983 and am extremely grateful for their efforts to launch the field as we know it today. I had already studied the core literature in the philosophy of the social sciences, but it was not until my grad studies in economics at the University of Michigan that I undertook a systematic study of the philosophy of economics, in 1985, as a reading course with Alan Gibbard. We read Sen, Harsanyi, Tversky and Kahneman, among others. There were only a few jobs that listed the philosophy of economics as a field, but I managed to secure one of them, a two-year post at the University of Colorado-Boulder. That was my second job. My first and also temporary job was at Michigan State University, and I had the good fortune to be part of a regular seminar that Warren Samuels ran, with John B. Davis, and Zohreh Emami as members. By 1985 I had also met many of the other key contributors, Neil De Marchi, Mark Blaug, Mary Morgan, Philip Mirowski, and Bruce Caldwell.

Which thinker was most influential for you during your early formative years, during graduate studies generally? Was there any one thinker that really marked you? 
That is a very hard question to answer! I suppose I would single out Thomas Kuhn, whom I had the privilege of meeting and talking to as a graduate student, and then much later as a fellow at MIT in 1995. I definitely preferred his work to Popper or Lakatos. I also learned a great deal from the work of Amartya Sen and Ian Hacking. Ian had arrived at the University of Toronto in the fall of 1983, when I defended my thesis, and he was part of the examining committee. D. McCloskey came to speak at Toronto in 1983, on the rhetoric of economics and so did Stephen Toulmin on his evolutionary epistemology. Both talks were influential and there were subsequent interactions in the years ahead.

Your doctoral thesis was on a key neoclassical revolutionary, William Stanley Jevons. This work culminated in your first monograph, A world ruled by number (Schabas 1990). Can you describe the main thesis of this work? What factors drew you to work on Jevons in the first place?

Well, there were no books on Jevons at that time (now there are four), but the leading Jevons scholar in the 1970s, R. D. C. Black, had just finished issuing the seven volumes of the Jevons papers and correspondence. I had also worked in the Jevons archives in the John Rylands Library at Manchester and the British Library, but Black's volumes proved invaluable. By chance, I also found a large collection of Jevons letters at Seton Hall University in New Jersey; letters that Black knew existed but had not been able to find in time for his publications.

I was drawn to Jevons because he was a contributor to logic, philosophy of science and economics, and because he was the instigator of a revolution that had Kuhnian overtones. He also published in the natural sciences, meteorology, fluid mechanics, biology, chemistry, even music theory. Before I started to work on Jevons I had assumed that he had simply tried to dress economics up as a mathematical science but I came away with a completely different appreciation and came to realize that he actually had done something quite profound. Jevons via his work in logic had tried to understand the essence of mathematical reasoning and was one of the first logicists. This means that he tried to reduce mathematical core concepts to pure logic, a position made more famous by Bertrand Russell among others. Jevons influenced many of the logicians of the late nineteenth, early twentieth century, including John Venn and Gottlob Frege. Similarly, Jevons's lengthy work, Principles 
of science, built on the work of John Hershel. Both were fallibilitists with a strong appreciation for the role of probabilistic thinking in science.

Over time, I came to realize that Jevons was a much richer and more original thinker than I had expected, and that there was not any dose of insincerity to his efforts to see that economics, as he put it, must be necessarily mathematical. I came to believe that his argument had some merit insofar as the phenomena of economics are numerical and thus as intrinsically mathematical as those in physics. Take the interest rate, for example; it is given to us as number and does not require any mapping as would be the case in say astronomy (mapping light points using spherical trigonometry). The title of my book comes from Jevons, that as a neo-Pythagorean he truly believed that "the world is ruled by number". Not only is the world of the economist replete with numerical facts, prices and quantities exchanged in the market place, but for Jevons even our individual minds, in making the decisions in the marketplace, are essentially doing the calculus.

Jevons hoped to make economics more scientific but he was quite aware that certainty eludes our grasp. He was not just thinking "oh, physics is this wonderful science and I am going to make economics like physics" because he did not think physics was the wonderful science! He could see, as Hershel did, that our ability to know the physical world is significantly limited.

In your more recent book entitled, The natural origins of economics (Schabas 2005), you argue that such fundamental economic thinkers as Adam Smith and François Quesnay did not view human economic activity as located "outside" of physical nature and that only gradually did economics come to be denaturalized. What exactly do you mean by this?

Well, thank you for that. That is a nice rendition. First let me say that the word 'nature' can mean virtually whatever one wants, and so one has to place it in a historical context. And second, the process of denaturalization has not been completed. There are still ways in which the discourse of economics overlaps with and draws upon our understanding of natural phenomena. But the early modern economists did not see their phenomena as distinct from the phenomena of what they took to be the natural realm. There was no clear sense in which there was a distinct realm called 'the economy'. 
Quesnay exemplifies this point of view. His tableau depicts a flow of material goods from one sector to another, without any deliberation. Wealth grows entirely through the gifts of nature and we are part of this natural order. David Hume's specie-flow mechanism is similar in that humans are part of the mechanism but are as governed by natural laws as the tides of the ocean.

And then, towards the middle of the 19th century, economics underwent what you describe as a denaturalization process, largely at the hands of John Stuart Mill. Can you describe this process?

Mill still wants to say that political economy is half physical and half mental. And I am sure that if you pushed an arch-rationalist, even an Austrian, they would have to say that there is some physical description to economic phenomena. But for neoclassical economists, everything stems from individual minds, from utility maximization, and in that sense is set apart from physical nature. The marketplace was redefined as information, not a physically located institution. Individuals have different predilections for consumer goods, risk, and time and, precisely because no two of us are alike, that gives rise to economic phenomena. That approach was not prevalent in the 18th and early 19th centuriesthen theory was oriented around three classes with little to no differentiation internal to each class. The strong methodological holism fit well with their commitment to inexorable laws in the economy, the laws of Malthus or Ricardo.

Economists continue to borrow methods and metaphors from the natural sciences. Phil Mirowski is exactly right in saying that early neoclassical economists adopted techniques from thermodynamics. It is not that they stopped drawing on science for inspiration, but that they conceived of the phenomena differently, as the product of human deliberation.

Right, so human agency became the proximate cause of economic phenomena. But surely this is a surprising thesis given that Mill, in his Principles of political economy, explicitly recognizes nature's agency. How do you square this circle?

Well, I think Mill is the pivotal figure insofar as he urges readers to see the mental origin of some economic laws, but he also emphasizes the powers of nature to produce our goods. For Mill and the earlier classical economists, no one individual decides to promote the increase in the 
rent, defined as a return to the natural attributes of the soil. Rents arise in a stylized and law-like fashion that is perceived to be beyond human control. Population growth is grounded in natural passions and entails diminishing returns in the agrarian sector as we cultivate, necessarily, inferior grades of land. Wages rise and profits fall. The iron law of wages best captures the sense in which human agency is impotent in comparison to what nature delivers. When you get to the neoclassical economists, however, particularly by the 1930s with the recognition of macroeconomics as a separate pursuit, one finds a strong belief that we can engineer the economy, that we are not limited by scarcity or human frailties (passions). Ricardo and Malthus sound extremely odd to our twenty-first century sensibility. Now we can use monetary easing or corporate tax cuts to solve almost any problem, or so we are told.

For the future of economics, do you envision the discipline reestablishing itself "in nature"? If so, what would this mean exactly, especially how economics might relate to the natural sciences and life sciences, such as biology and ecology?

It is hard for me to say what the future will hold but I do sense that economists are taking global warming very seriously and this has drawn them all the more to accounts in ecology and the life sciences more generally.

In the early 1990s you wrote on the history of economics as history of science. Have you changed your position?

I hold onto that same position to this day, and wrote about it again in 2002. I was invited to write on that topic by Roy Weintraub for a symposium in the Spring 1992 issue of HOPE. Roy asked me because I was one of the only people in the history of economics practising in a history of science department and trained in that field-in HPS. But that said, I never wanted to say that we should not do some history of economics in economics departments. I just wanted to point out that the field was not really growing and that if anything the field was losing ground in economics departments. It is prudent to think about a different patron or institutional setting, mainly history and philosophy of science or sciences studies. There is much more interest in economics within that community, say with the work of Donald Mackenzie or Nancy Cartwright. The volume that Neil De Marchi and I put out on Oeconomies in the age of Newton (2003) helped to situate the history 
of economics within the history of science, as did Mirowski's Natural images in economic thought (1994). I still believe that it is better, all things being equal, to do the history, philosophy, and sociology of economics as just one science among many, that is, within the broader rubric of science studies. But I also want mainstream economists to read and take our courses, just as biologists should study the history and philosophy of biology. I think we would have more impact on economists if we were more detached from them rather than seeking their direct approval, not to mention beholden to their budget constraints.

Might there be something distinctively valuable about the work of a historian of economics working from within an economics department?

I think to do the history of economics well one has to have some good training in economics and it would be ideal if one continues to interact with economists in seminars, colloquiums, and conferences. Those who contribute well to the history and the philosophy of biology, for example, tend to interact with biologists. They tend to get to know them, go to their labs and keep up with the latest research, but are housed in separate departments of HPS or STS. This is all for the good. But it seems obvious, at least in North America, that economists have lost interest in the history of economics. I think we could rekindle an interest if we first gain some distance and cultivate ourselves more fully, if we are less beholden to the disciplinary norms that govern the profession of economics. He who pays the piper calls the tune.

The history of psychology is a good example. It used to be done by retired psychologists and was not, for the most part, done well. Those who finally shaped the field did so by gaining autonomy, within departments of the history of science, for example Robert Richards and Jan Goldstein at Chicago, or Anne Harrington at Harvard. Now most of the top programs in science studies offer the history of psychology and find it benefits from attending to intersections with the history of physics or biology. It is a field that has truly matured. The history of mathematics, by contrast, has not. It still tends to be done by retiring mathematicians in math departments and done poorly. The few historians of science who specialize in the field are always bemoaning the fact that their subject is neglected. 
I am delighted that two of the most influential scholars of my generation, Phil Mirowski and Mary Morgan, fit this description. Both have become established names in HPS or science studies, precisely because they have crossed over into those worlds, publishing in the key journals and speaking at the annual meetings. Mirowski now holds a cross-appointment in the HPS program at Notre Dame, while Morgan works closely with HPS scholars at the LSE and abroad.

I understand that you are now working on David Hume's economics. When most people think of the history of economics, they immediately think of Adam Smith and not his best friend, David Hume. Why is this? What is Humean economics (if I can use such a term)?

Well, it would be hard to answer any of this in a short amount of time; that is why I need a book! Hume is very well-known in the history of monetary thought and as a proponent of the moral sciences, an eighteenth-century term that roughly corresponds to our social sciences. I would not say that Hume is ignored among the cognoscenti but there is no question that Smith is the best known economist outside academia, and that The wealth of nations is seen as equivalent to, say, Newton's Principia.

Hume wrote a number of essays on economics and he developed many rich insights about property and money in his main philosophical texts. I hope to show that there is a thread of economic thinking all the way through Hume's publications and correspondence. He is very interested in economic issues, fiscal and trade policy, money and banking. He interacts and corresponds with most of the leading economists at the time. But probably his most important contribution is his understanding of the epistemological limits of what he called the science of commerce. He believed that we have a better grasp of our ignorance in economics than we do in physics and, in that sense, economics may be superior to physics. In both fields, of course, he emphasizes how little we know and how fragile that knowledge truly is.

One thing that always struck me with Hume's economics is his definition of wealth. The wealth of any nation consists in the people and commodities that constitute that nation.

Yes, he was keen to lift the veil of money and look at the physical properties of wealth. And he was very cosmopolitan in his thinking, 
placing weight on the migration of economic opportunities around the globe. Indeed, he believed there was a global justice to how wealth ebbed and flowed from one nation to the next. And, interestingly, he was not only as aware as Smith that America would be the next economic hegemony, but conjectured that China might one day surpass America.

Michel Foucault (1960) and Keith Tribe (1978) have argued that the theoretical concept of "the economy" is relatively new-having gained traction only over the last two hundred years. You (2009) recently argued for a similar thesis. Are there any methodological consequences that arise when we recognize that the economy is a mind-dependent theoretical entity?

Well, when you construct something in theory then there is always the question of whether or not you have captured the physical dimensions accurately. So, in physics one could argue that the electro-magnetic field of Maxwell's equations is just constructed on paper. The same thing is true for the economy. It is a theoretical construction made up of such leading indicators as the money supply, population, interest rate, consumer price index, gross national product, and so on. We have to stitch all of these things together and then somehow we create this economy, but it is really on paper. Furthermore, most of our indicators can only be measured with a temporal lag and slightly imperfect tools. This means we need to attend to methods and recognize what is merely conventional.

You are now embarking on a new research project on the history and philosophy of bioeconomics. What have you discovered so far and what do you hope to accomplish with your project?

The journal Bioeconomics is only a little more than a decade old, but conceptual and methodological trade between economic and biological discourse, to speak anachronistically, reaches back to at least the 17th century. There is also reason to believe that both are trying to make sense of how life is produced and reproduced, distributed, and so forth. In the early modern period, the most common term was the "Oeconomy of nature", and it included all life forms and even the earth's atmosphere and crust. Evolutionary thinking took hold in both 
discourses, starting in the mid-18th century. I would like to revisit this and see to what extent both disciplines make use implicitly of the same predilections, for efficiency for example. Darwin is replete with economic metaphors and natural selection itself is a mechanism that could be construed as bringing efficiency to the distribution of life forms. Bioeconomists at present are interested in understanding non-human animals in economic terms, or understanding the biological constraints of economic processes. These are interesting pursuits that might blend with ecology and environmental science. For now, I am trying to write more articles before getting to a book.

As I understand it, the conceptual trade between economics and biology is a significant theme in this project. Are such exchanges between these sciences surprising?

Most of science feeds on analogical trade. Besides what I just said about Darwin, other examples from that period are Milne-Edwards's use of the idea of division of labour in physiology, or Marx's use of reproduction in concepts of capital. If economics is defined as the allocation of scarce resources among alternative ends, or as making the best of things, I think you can see that it is an open book as to how you configure those resources or those ends.

Let me switch gears for a moment. What, to your mind, is the purpose of doing the philosophy of economics?

Well, I think the general rule in the philosophy of science is that many scientific practitioners, with a few exceptions, cannot take the time to look at the foundational issues regarding their science, for all the reasons advanced by Kuhn among others. Why do I make these assumptions? Why do I use the particular methods? Philosophers of economics do have the time and training to ask these questions-to ask them in light of what has developed in philosophy more generally. They can also step away and assess the extent to which economic discourse is advancing or retreating on specific topics, or even recycling old ideas. Those making up economic theory and practice do not always have the time or tools to do this, although there are some exceptions, Amartya Sen, for example. 
Today, philosophers of economics and methodologists are wont to say that their work should be practically relevant for economists. What is your position on this matter? Are philosophers of economics Lockean under-labourers of some kind or merely a special breed of reflective economists?

Well, I think you could be either. But again, going back to my breaking away idea, I believe that it would be good for us to be neither, to develop our discipline of the history and philosophy of economics independently of the discipline of economics. We might end up with results that would have more impact in the long run. As long as we write for economists, we will try to copy their methods (i.e., overuse mathematical models) or employ their concepts, and do ourselves disservice. I realize this sounds idealistic, because we need more resources to gain this autonomy, but it is still good to spell out that end as an ideal to aim for over time. I would still hope that the work done in the history and philosophy of economics would result in a better economics.

So have you contradicted yourself? Do you in fact share the same goal as those who would be against "breaking way"?

Well, we always want to influence the world, of course, and there is reason to think that economists have not done the best job of giving us a world of full employment or reducing significant inequality of wealth or income, for example. Maybe they should not be held accountable! But if we hope to make a better world, one possible path is to understand better how it works. That said, doing history for its own sake, or in my case, the history and philosophy of economics for its own sake, is a possible way to cultivate a kind of wisdom and a set of insights that can be used over time. I think the indirect method is better; certainly direct methods to hit economists on the head have not worked. The philosophy of biology, for example, has come unto its own in the last 20-25 years. It has grown dramatically and is mostly done by people who are not practicing biologists. And I think it really has had an impact on biology, on deep questions pertaining to the process of speciation, for example. We have to separate ourselves off and do our field well in accordance with our own disciplinary standards. We cannot predict what the results will be, but my hope is that they will have more of an effect than if we are just trying to chase after and conform to the latest fashion in economics. 


\section{REFERENCES}

Foucault, Michel. 1970. The order of things: an archaeology of the human sciences. New York: Vintage.

Mirowski, Philip. 1994. Natural images in economic thought: "markets read in tooth and claw". Cambridge: Cambridge University Press.

Schabas, Margaret. 1990. A world ruled by number: William Stanley Jevons and the rise of mathematical economics. Princeton (NJ): Princeton University Press.

Schabas, Margaret. 1992. Breaking away: history of economics as history of science. History of Political Economy, 24 (1): 187-203.

Schabas, Margaret. 2002. Coming together: history of economics as history of science. In The future of the history of economics, ed. E. Roy Weintraub. Durham (NC): Duke University Press, 208-225.

Schabas, Margaret. 2005. The natural origins of economics. Chicago: Chicago University Press.

Schabas, Margaret. 2009. Constructing "the economy". Philosophy of the Social Sciences, 39 (1): 3-19.

Schabas, Margaret, and Neil De Marchi (eds.). 2003. Oeconomies in the age of Newton. Durham (NC): Duke University Press.

Schabas, Margaret, and Carl Wennerlind (eds.). 2008. David Hume's political economy. London: Routledge.

Tribe, Keith. 1978. Land, labour, and economic discourse. London: Routledge.

Margaret Schabas's Webpage: http://faculty.arts.ubc.ca/mschabas/ 